\title{
WALL-EYED BILATERAL INTERNUCLEAR OPHTHALMOPLEGIA (WEBINO SYNDROME) AND MYELOPATHY IN PYODERMA GANGRENOSUM
}

\author{
MARCO AURÉLIO LANA * PAULO ROBERTO R. MOREIRA** \\ LEONARDO B. NEVES ***
}

\begin{abstract}
SUMMARY - A 35-year-old female with pyoderma gangrenosum developed paraparesis with a sensory level at L1. Three months later she complained of diplopia and was found to have bilateral internuclear ophthalmoplegia with exotropia and no ocular convergence. The term Webino syndrome has been coined to design this set of neuro-opthalmologic findings. Although it was initially attributed to lesions affecting the medial longitudinal fasciculus and the medial rectus subnuclei of the oculomotor complex in the midbrain the exact location of the lesion is still disputed. In the present case both myelopathy and webino syndrome were probably due to vascular occlusive disease resulting from central nervous system vasculitls occurring in concomitance to pyoderma gangrenosum.
\end{abstract}

Oftalmoplegia internuclear bilateral e exotropia (síndrome de Webino) e nielopatia no pioderma gangrenosum.

RESUMO - O termo Webino é formado pelas iniciais dos componentes da sindrome (walleyed bilateral internuclear uphthalmoplegia), havendo também perda da convergência ocular. Relatamos o caso de uma paciente de 35 anos de idade, com pioderma gangrenosum, que desenvolveu subitamente mielopatia com nível sensitivo em L1 e, trés meses depois, quadro súbito de oftalmoplegia internuclear bilateral, exotropia e perda de convergência. Há. poucos casos de síndrome de Webino relatados na literatura, a maioria deles secundária a esclerose múltipla e a doenç vascular cerebral. A localizaçāo da lesão responsável pela sindrome ainda năo está bem estabelecida mas, acredita-se que os fascículos longitudinais mediais e os subnúcleos dos retos mediais do complexo oculomotor no mesencéfalo sejam afetados, embora não haja ainda confirmação anátomo-patológica. O pioderma gangrenosum é condição caracterizada por úlceras de crescimento rápido e de bordas elevadas com halo eritematoso localizadas preferencialmente na cabeça, tronco e membros inferiores. Embora sua natureza ainda seja desconhecida, parece ser secundário a vasculite subjacente, estando associado a grande variedade de doenças sistèmicas. No caso presente, a ocorrência da sindrome de Webino e de mielopatia sugere que as lesòes no sistema nervoso sejam de natureza vascular, provavelmente secundárias a vasculite. Este é o primeiro relato wa literatura de complicações neurológicas do pioderma gangrenosum e da associaçăo de mielopatia à sindrome de Webino.

Wall-eyed bilateral internuclear ophthalmoplegia (Webino syndrome) is a variant of Cogan's anterior internuclear ophthalmoplegia with exotropia in primary position. It has been attributed to lesions affecting the medial longitudinal fasciculus and the medial rectus subnuclei of the oculomotor complex. Only a few cases of Webino syndrome have been reported in the literature. We describe a patient with pyoderma gangrenosum who devcloped bilateral internuclear ophthalmoplegia with exotropia, loss of convergence and myelopathy in the course of the disease. To our knowledge neither nturological complications of pyoderma gangrenosum nor association of Webino syndrome to myelopathy have been described previously.

Federal University of Minas Gerais Medical School (UFMG): * Associated Professor of Neurology; ** Neurologist; *** Dermatologist. 


\section{CASE REPORT}

MSL, a 35-year-old female was admitted to the hospital with history of recurrent ulcers in left arm and thigh since the age of 18 years. In the last two years she developed chronic urinary infection and had been treated with antibiotics. She had also been given talidomlde, chlorphazimine and DDS as treatment for pyoderma gangrenosum in another hospital, where the diagnosis was made through a skin biopsy. On admission the patient presented a large painful necrotic ulcer surrounded by an erythematous halo in the left thigh (Fig. 1) and signs of old inative dermatological lesions on the left arm. There was no neurological or ophthalmological complaint. Physical examination was unrevealing except for the skin lesions. Admission laboratory work-up was as follows: red blood cell count $3,500,000$ per cubic millimeter, hemoglobin $10,5 \mathrm{~g} / \mathrm{dL}$, hematocrit $35 \%$, and white blood cell count 5,300 per cubic millimeter. Serum glucose, creatinine, BUN, thyroid and liver function studies and protein electrophoresis showed normal values. Serum VDRL, FTA-ABS, antinuclear antibody titers LE cell preparation were also negative as were roentgenograms of the chest and gastrointestinal series. Biopsy specimens taken from the erythematous area at the border of the lesion on patient's left thigh disclosed lymphocytic vasculitis with endothelial swelling, fibronoid necrosis and extravasation of erythrocytes and lymphocytes (Fig. 1). As the patient was being treated with azathioprine and steroids she suddenly developed paraparesis and urinary retention. Neurological consultation at this time disclosed paraparesis with a sensory level at $L$. The deep tendon reflexes were hypoactive and Babinski sign could not he elicited. Lumbar puncture showed an opening pressure of 120 $\mathrm{mmH}_{2} \mathrm{O}$, clear cerebrospinal fluid with 3 lymphocytes per cubic millimeter, glucose content of $100 \mathrm{mg} / \mathrm{dL}$ and protein content of $12 \mathrm{mg} / \mathrm{dL}$ with normal electrophoretic fractions. Three
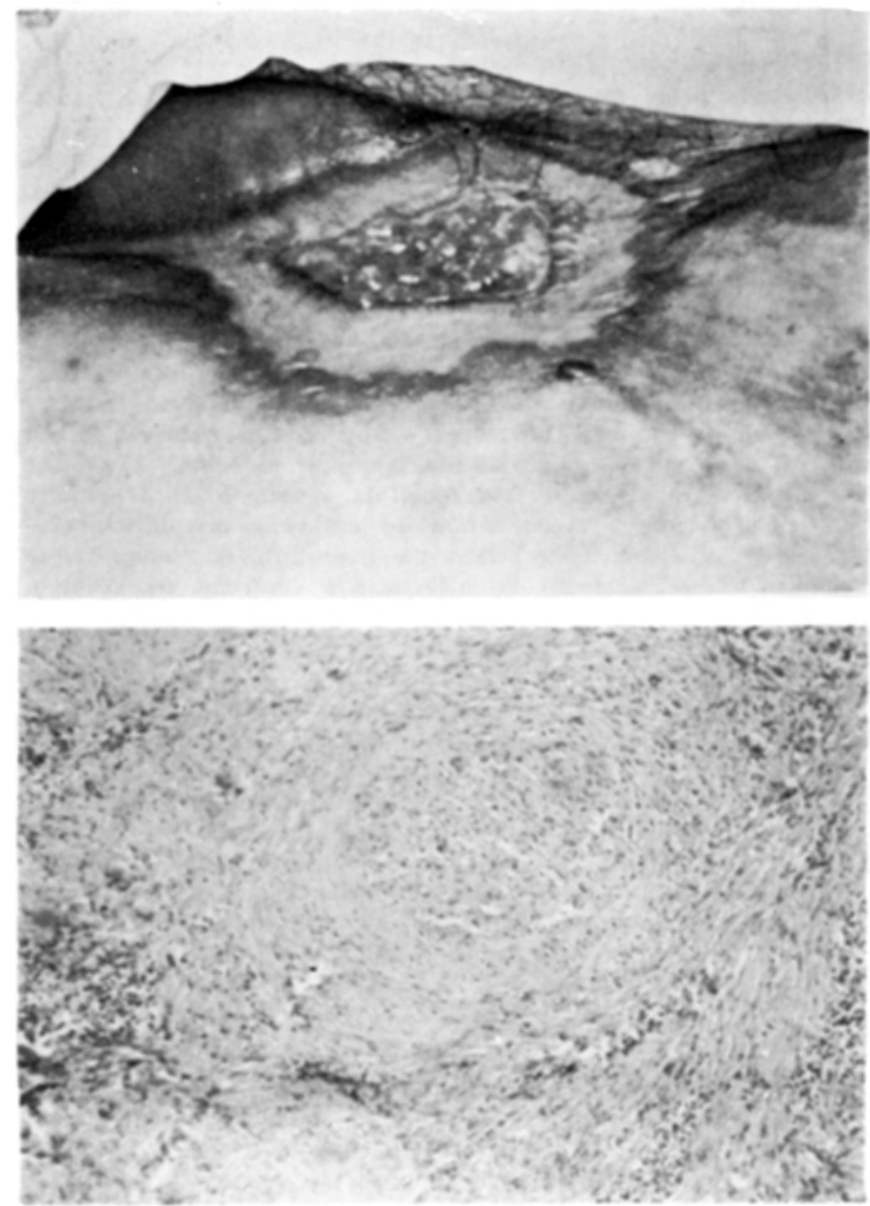

Fig. 1 - Case MSL. Above: large necrotic ulcer on patient's left thigh. Below: lymphocytic vasculitis with fibrinoid necrosis at the border of the ulcer. 
months later while on physical therapy she suddenly experienced left hemiparesis and diplopia. Neurological re-evaluation showed exotropia in primary position, bilateral medial rectus palsy on attempted horizontal gaze on either direction with nystagmus of the abducting eye (Fig. 2). Vertical gaze was normal and there was a loss of ocular convergence. The pupils were $3 \mathrm{~mm}$ in size, round and fully reactive to light. Fundoscopic examination and visual fields were normal. There were a left central facial weakness, moderate left hemiparesis and a residual weakness on the right lower limb. Muscle stretch reflexes were decreased on the left upper limb but brisk on both lower extremities. Bilateral Babinski sign was present and sensory level at L1 persisted unchanged. High quality computed tomographic scan of the head exhibited no abnormalities.

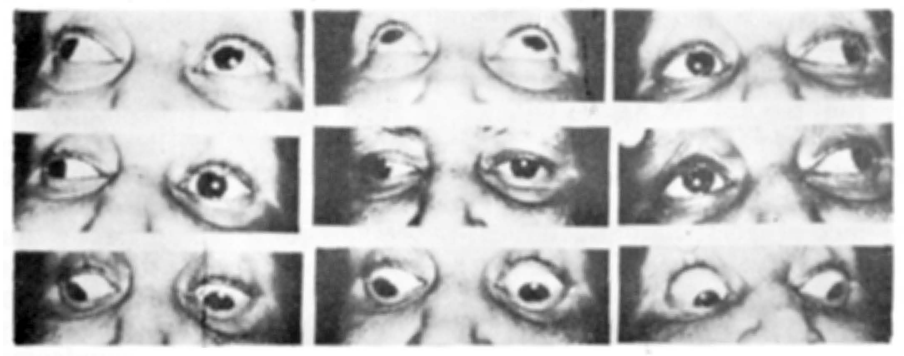

Fig. 2 - Case MSL. Bilateral medial rectus palsy on attempted horizontal gaze and exotropia in primary position. Vertical gaze is normal.

\section{COMMENTS}

Internuclear ophthalmoplegia is a well-characterized clinical syndrome manifested by paresis of adduction on attempted horizontal gaze associated with jerk nystagmus of the abducting eye. Vertical nystagmus with attempted upward gaze and loss of convergence may be concomitant features. Although the clinical description of the syndrome is attributed to Wilson 36 in 1906 , some authors 13 date back its recognition to about 1864. The role of the medial longitudinal fasciculus (MLF) in mediation of conjugate eye movements was first suspected by Muskens 22 as early as 1914. This suspection was confirmed ten years later through the first pathological study of a case of internuclear ophthalmoplegia 31. Since then it has been well demonstrated that lesions involving the MLF connecting the pontine paramedian reticular formation (PPRF) and the ipsilateral abducens nucleus with the contralateral medial rectus subnucleus in the midbrain produce failure of the medial rectus on the side of the lesion to act in horizontal gaze and nystagmus of the abducting eye. Weakness of adduction may range from complete inability to adduct the eye beyond midline to only a mild decrease in velocity of adducting saccades without any limitation of adduction. The origin of the contralateral abducting nystagmus is still a matter of controversy. Some authors believe that it may reflect the effects of convergence 33 , impaired inhibition of the contralateral medial rectus 24 , interruption of descending internuclear fibers projecting to the abducens nucleus 14 , a gaze-evoked nystagmus 3 , or even adaption to the contralateral medial adduction weakness 2 .

Internuclear ophthalmoplegia has been divided into anterior and posterior types 5 . When convergence is absent concomitantly with adductor paralysis it is designated "anterior internuclear ophthalmoplegia», the lesion involving the rostral portion of the MLF conducting the impulses for convergence from the pretectal region to the third nerve nucleus. This convergence tract is indeed located anterior to the third nerve nucleus 17. On the other hand in «posterior internuclear ophthalmoplegia» there is preservation of convergence despite absence of voluntary adduction, and a caudal lesion sparing the medial rectus subnucleus of the oculomotor nuclear complex can be assumed 5. It has been established however that while the posterior internuclear ophthalmoplegia is clinically useful as a localizing sign consistently pointing to a caudal lesion, the absence of convergence in the setting of an internuclear ophthalmoplegia (the anterior type) does not necessarily imply a rostral lesion involving the medial rectus nuclear subdivision 21. Unilateral internuclear ophthalmoplegia is usually due to an infarct of the midbrain tegmentum 29; demyelinating disease, tumors 
and infections are less frequent causes. On the other hand the most common cause of bilateral internuclear ophthalmoplegia is multiple sclerosis $\mathbf{5}$, although posterior fossa tumors 6, brainstem infection 29, Arnold-Chiari malformations with hydrocephalus 6, head trauma 1,25 , basilar artery disease 8 , carcinomatous meningitis 9 , tuberculous meningitis 16 , cryptococcal meningitis 11 , systemic lupus erythematosus 7 , intrathecal chemotherapy and cranial irradiation 18 , syphilis 29 , periarteritis nodosa 4 , spinocerebellar degenerations 35 and branched-chain ketoaminociduria 19. Myasthenia gravis 5, abetalipoproteinemia 37 and coma caused by overdose of phenytoin 30 , narcotics 26 or barbiturates 23,27 may produce ocular findings similar to bilateral internuclear opthalmoplegia.

The term Webino syndrome (wall-eyed bilateral internuclear ophthamoplegia) was coined by Lubow 36 to describe patients with bilateral adduction paresis, absence of ocular convergence and exotropia. Lubow believed that the syndrome was caused by lesions involving the medial longitudinal fasciculus bilaterally in the midbrain together with the medial rectus subnuclei of the oculomotor complex. There have been only a few cases of Webino syndrome reported in the literature, most of them caused by occlusive vascular or demyelinating diseases 10,20,32. An additional case was due to a tuberculous granuloma in the midbrain that presumably affected the $M L F$ and the medial rectus subnuclei of the oculomotor complex by mass effect 16 . In a recent reported case of Webino syndrome caused by multiple sclerosis autopsy did not reveal any lesion in the medial rectus subnuclei of the oculomotor complex leading their authors 32 to suppose that lesions in more than one locus may be responsible for eliciting the syndrome. Others have attributed the syndrome to lesions affecting the PPRF and the MLF but this hypothesis has not been confirmed by pathological studies. As loss of convergence is concerned a supplemental anatomic explanation may not be necessary as it commonly occurs in long-standing disruptions of ocular fusion 10. It has been proposed however that interruption of corticofugal fibers from frontal, parietal or occipital eye fields may play a role in the convergence dysfunction 32 .

Pyoderma gangrenosum is an uncommom ulcerative skin condition with distinctive clinical appearance comprising a destructive burrowing ulcer with an irregular margin and a ragged purple-red overhanging edge 15 . It typically starts as an isolated sterile pustule or nodule, often on one of the lower extremities but rapidly breaks down and evolves into an ulcer that is painful, enlarging and necrotic. It has been reported in association with a wide variety of systemic diseases including ulcerative colitis, Crohn's disease, theumatoid arthritis, chronic myeloid leukemia, agammaglobulinemia, respiratory infections and post-surgical interventions 12 . Histopathologic and immunopathologic study 34 of pyoderma gangrenosum has shown the most characteristic changes are those of lymphocytic vasculitis, mild fibrinoid necrosis of the blood vessel walls, disruption of the blood vessel structure and thromboses of the lumen of the vessels.

It seems reasonable to assume therefore that the lesions involving brainstem structures causing Webino syndrome and that causing myelopathy in the present case probably resulted from vasculitis and occlusive vascular disease.

\section{REFERENCES}

1. Baker RS - Internuclear ophthalmoplegia following head injury. J Neurosurg 51:552, 1979.

2. Baloh RW, Yee RD, Honrubia B - Internuclear ophthalmoplegia: 1. Saccades and dissociated nystagmus. Arch Neurol 35:484, 1978.

3. Bender MB, Weinstein EA - Dissociated monocular nystagmus with paresis of horizontal ocular movements. Arch Ophthalmol 21:226, 1939.

4. Christoff N, Anderson PJ, Nathanson M - Problems in anatomic analysis of lesions of the medial longitudinal fasciculus. Arch Neurol 2:293, 1960.

5. Cogan DG - Internuclear ophthalmoplegia, typical and atypical. Arch Ophthalmol $84: 583,1970$.

6. Cogan DG, Wray S - Internuclear ophthalmoplegia as an early sign of brainstem tumors. Neurology 20:629, 1970.

7. Cogan M, Klinne LB, Duvall ER - Bilateral internuclear ophthalmoplegia in systemic lupus erythematosus. J Clin Neuro-Ophthalmol 7:69, 1987.

8. Deveraux MW, Brust JCM, Keane JR - Internuclear ophthalmoplegia caused by subdural hematoma. Neurology 27:251, 1979. 
9. Ford SC. Cruz J, Biller .T, Wayme L, White DR - Bilateral internuclear ophthalmoplegia in carcinomatous meningitis. J Clin Neuro-Ophthalmol 3:127, 1983.

10. Gonyea EF - Bilateral internuclear ophthalmoplegia: association with occlusive cerebrovascular disease. Arch Neurol 31:168, 1974.

11. Gonyea EF, Helman KM - Neuro-ophthalmic aspects of central nervous system cryptococcosis. Arch Ophthalmol 87:161, 1972.

12. Guilhou JJ, Guillot B, Meynadier J - Pyoderma gangrenosum: 14 observations personnelles et revue de la litérature. J Maladies Vasc 12:202, 1987.

13. Harrington RB, Hollenhorst RW, Sayre GP - Unilateral internuclear ophthalmoplegia. Arch Neurol 15:29, 1966.

14. Henn V, Buttner-Ennever JA, Kepp $\mathbf{K}-$ The primate oculomotor system: I. Motoneurons: a synthesis of anatomical, physiological and clinical data. Hum Neurobiol 1:7\%, 1982.

15. Holt PJA, Davies MG, Saunders KC, Nuki G - Pyoderma gangrenosum: clinical ar.d laboratory findings in 15 patients with special reference to polyarthritis. Medicine 59:114, 1980 .

16. Inocencio FP, Baceller $\mathrm{R}$ - Tuberculosis granuioma in the midbrain causing wall-eyed bilateral internuclear ophthalmoplegia (Webino). J Clin Neuro-Ophthalmol 5:31, 1985.

17. Kupfer C, Cogan DG - Unilateral internuclear ophthalmoplegis: a clinicopathological case report. Arch Ophthalmol 75:484, 1966.

18. Lepore FE, Nissenblatt $\mathbf{M J}$ - Bilateral internuclear ophthalmoplegia after intratecal chemotherapy and cranial irradiation. Am J Ophthalmol 92:851, 1981.

19. MacDonald JJ, Sher PK - Ophthalmoplegia as a sign of metabolic disease in the newborn. Neurology 27:971, 1977.

20. McGettrick P, Eustace P - The webino syndrome. Neuro-Ophthalmol 5:109, 1985.

21. Miller NR - Walsh and Hoyt's Clinical Neuro-Ophthalmology. Ed 4 . Williams and Wilkins, Baltimore, 1985.

22. Muskens LJJ - An anatomico-physiological study of the posterior longitudinal bundle in its relation to forced movements. Brain $36: 362,1914$.

23. Plum F, Posner JB - Diagnosis of Stupor and Coma. Ed 3. F.A. Davis, Philadelphia, 1980.

24. Pola J, Robinson DA - An explanation of eye movements seen in internuclear ophthalmoplegia. Arch Neurol 33:447, 1976.

25. Rich JR, Gregorius FK, Hepler RS - Bilateral internuclear ophthalmoplegia after trauma. Arch Ophthalmol $92: 66,1974$.

26. Rizzo $M$, Corbett $\mathrm{J}$ - Bilateral internuclear ophthalmoplegia reversed by naloxone. Arch Neurol 40:242, 1983.

27. Simon RP - Forced downward ocular deviation occurrence during oculo-vestibular testing in sedative drug-induced coma. Arch Neurol 35:456, 1978.

28. Smith JL - Internuclear ophthalmoplegia. J Clin Neuro-Ophthhalmol 6:66, 1986.

29. Smith JL, Cogan DG - Internuclear ophthalmoplegia: a review of 58 caseg. Arch Ophthalmol 61:687, 1959.

30. Spector RH, Davidoff RA, Schwartzman RJ - Phenytoin-induced ophthalmoplegia. Neurology 26:1031, 1976.

31. Spiller WG - Ophthalmoplegia internuclearis anterior: a case with necropsy. Brain 47:345, 1924 .

32. Strominger MB, Miney EJ, Strominger AI, Strominger NL -- Bilateral internuclear ophthalmoplegia with absence of convergent eye movements: clinicopathologic correlation. $\mathrm{J}$ Clin Neuro-Ophthalmol 6:57, 1986.

33. Strond MH, Newman NM, Keltner JL, Gay AJ - Abducting nystagmus in the medial longitudinal fasciculus (MLF) syndrome-internuclear ophthalmoplegia (INO). Arch Ophthalmol $92: 2$, 1974 .

34. Su WPD, Schroeter AL, Perry HO, Powell FC - Fistopathologic and immunopathologic study of pycilerma gangrenosum. J Cit Pathol 13:323, 1986.

35. Weiner LP, Konigsmack BW, Stoll J, Magladery JW - Hereditary olivo-pontocerebellar atrophy with retinal degeneration: report of a family through six generations. Arch Neurol 16:364, 1976.

36. Wilson SAK - Case no 3, presented at the clinical meeting of the Neurological Soclety of the United Kinojgom, on March 29, 1906. Brain 27:298, 1906.

37. Yee RD, Cogan DG, Zce WS -- Ophthalmoplegia and dissociatcd nystagmus in abetalipoproteinemia. Arch Ophthalmol 94:571, 1976. 